\title{
EMISSIVITY OF ALUMINIUM ALLOY USING INFRARED THERMOGRAPHY TECHNIQUE
}

\author{
EMISIVNOST ALUMINIJEVE ZLITINE Z UPORABO INFRARDEČE \\ TERMOGRAFIJE
}

\author{
Zorana Lanc, Branko Štrbac, Milan Zeljković, Aleksandar Živković, Miodrag Hadžistević \\ University of Novi Sad, Faculty of Technical Sciences, Department for Production Engineering, Trg Dositeja Obradovića 6, Novi Sad, Serbia \\ zoranalanc@uns.ac.rs \\ Prejem rokopisa - received: 2017-09-19; sprejem za objavo - accepted for publication: 2017-11-23
}

doi:10.17222/mit.2017.152

\begin{abstract}
Experimental determination of the emissivity of aluminum alloy Al 6082 depends on the surface roughness and temperature. The authors conducted an investigation on aluminum workpieces with different degrees of surface roughness during a continuous-cooling process, using the infrared thermography technique (ITT). The results obtained showed that the emissivity of the examined alloy increases with a larger surface roughness and decreases during the cooling process, its value ranging from 0.09 to 0.24 . It was concluded that the surface roughness has a greater influence on the increase of the emissivity at higher temperatures, which can be seen in three-dimensional infrared images (3D IR). Multiple-regression analysis confirmed a strong correlation between the examined parameters and the emissivity, and an original multiple-regression model was determined. Keywords: emissivity, aluminium alloy, infrared thermography technique (ITT), three-dimensional infrared images (3D IR), regression analysis
\end{abstract}

Eksperimentalno določanje emisije aluminijeve zlitine Al 6082 glede na hrapavost in temperaturo površine. Avtorji so izvedli raziskavo na aluminijastih obdelovancih z različnimi stopnjami hrapavosti površine med postopkom neprekinjenega hlajenja in z uporabo infrardeče termografije (ITT). Dobljeni rezultati so pokazali, da se emisija preizkušane zlitine poveča z večjo površinsko hrapavostjo in se med procesom hlajenja zmanjša, njena vrednost pa se giblje med 0,09 in 0,24. Pri višjih temperaturah ima hrapavost večji vpliv na povečanje emisij. Kar lahko vidimo na tridimenzionalnih infrardečih slikah (3D IR). Večkratna regresijska analiza je potrdila močno korelacijo med preiskovanimi parametri in emisivnostjo. Določen je bil večkratni regresijski model.

Ključne besede: emisivnost, aluminijeva zlitina, infrardeča termografija (ITT), tridimenzionalne infrardeče slike (3D IR), regresijska analiza

\section{INTRODUCTION}

The use of the infrared thermography technique (ITT) for a non-contact temperature measurement has rapidly increased in the recent years in all areas where changes in the temperature reflect the quality and state of a product or a process. ${ }^{1,2}$ The ITT works on the principle of the transformation of spatial variations in the emitted infrared radiation from the surface of an observed object into a two-dimensional infrared (IR) image, where the differences in temperature distribution are presented as a range of colors or tones. ${ }^{3}$ The practical use of the ITT, however, has its limitations due to the emissivity of the observed body. ${ }^{4}$ The emissivity represents the ability of a body to absorb and emit heat. It depends on numerous factors such as the type of material, surface roughness, microstructure, temperature, wavelength, etc. ${ }^{5}$

Many authors investigated the effect of the mentioned parameters on the emissivity characteristics of materials, mainly metals and their alloys due to their low and varying emissivity. F. Zhang et al. ${ }^{6}$ determined the emissivity of pure titanium TA1, oxidized nickel and austenitic stainless steel by means of a special measuring apparatus using a monochromator with a diffraction grating. With the investigated range of wavelengths of $0.8-2.2 \mu \mathrm{m}$ and temperature range of $200-1000{ }^{\circ} \mathrm{C}$, it was shown that the emissivity of the examined metals slightly falls with an increase in the wavelength and rises with an increase in the temperature. B. Kong et al. ${ }^{7}$ analyzed the emissivity of nickel super alloy GH536 and five aeronautical alloys using a Fourier-transform infrared-spectroscopy spectrometer at wavelengths of $1-5 \mu \mathrm{m}$ and a temperature range of $127-927{ }^{\circ} \mathrm{C}$. The investigation showed that the emissivity of the examined alloys rises with an increase in the temperature and falls with an increase in the wavelength, while oxidation and flame treatment increase the emissivity. C. D. Wen et al. ${ }^{8}$ used multispectral radiation thermometry (MRT) to determine the emissivity of different aluminum alloys depending on the temperature, surface roughness and oxidation. ${ }^{8}$ The emission spectra of different alloys were similar in shape at the same temperature, but oxidation led to significant differences in the magnitude. An increase in the temperature and surface roughness mostly resulted in a higher emissivity of the examined alloys., ${ }^{9,10}$

While the previously mentioned investigations showed that the emissivity increases with the increase in the temperature and surface roughness during heating, 
this paper includes an investigation into the emissivity behavior of an aluminum alloy during a continuous-cooling process using ITT. The reason for this is the constancy of the factors, which influence the emissivity, especially the surface conditions of a measured workpiece and similar heating and cooling rates of metals. Three-dimensional infrared images (3D IR) were used in a more detailed analysis of the effects of the surface roughness and temperature on the emissivity characteristics of metals. This study considered the possibility of using a multiple-regression analysis for the theoretical determination of the emissivity, on the basis of the experimentally obtained data. In the frame of this study, we investigated the influence of the surface roughness and temperature on the emissivity of metals with the aim of checking whether the ITT can be used for a reliable temperature measurement of heated metal surfaces on the work equipment and, by implication, for an assessment of the risk of burn injuries.

\section{EXPERIMENTAL PART}

The experimental determination of the emissivity was conducted on the aluminum alloy Al 6082. Its mechanical properties are optimal for machining and metalworking; it has high thermostability and corrosion resistance. For the purpose of the experimental work, four workpieces were made with dimensions of $(150 \times 150 \times$ 10) $\mathrm{mm}$. The first workpiece was ground, whereas the other three were milled in different regimes of face milling with the aim of obtaining different surface qualities, i.e., roughness values. The roughness of the workpieces was measured with a contact method using a Mar Surf PS1 device. The mean roughness (roughness average, $R_{\mathrm{a}}$ ) was measured in 30 points uniformly distributed on the surface of the workpiece. The average value of the measured roughness $(\overline{R a})$ was taken as the surface roughness of the workpiece (Table 1).

Table 1: Surface roughness of the workpieces

\begin{tabular}{|c|c|c|}
\hline $\begin{array}{c}\text { Type of } \\
\text { machining }\end{array}$ & $\begin{array}{c}\text { Roughness (average) } \\
\overline{R a}(\mu \mathrm{m})\end{array}$ & Label \\
\hline grinding & 1.07 & $\mathrm{~A}_{1}$ \\
\hline \multirow{2}{*}{ milling } & 1.25 & $\mathrm{~A}_{2}$ \\
\cline { 2 - 3 } & 1.55 & $\mathrm{~A}_{3}$ \\
\cline { 2 - 3 } & 1.77 & $\mathrm{~A}_{4}$ \\
\hline
\end{tabular}

The usual method for determining the emissivity by means of an infrared (IR) camera is based on simultaneous heating of a workpiece, measuring the temperature by means of an IR camera and measuring the reference temperature on the analyzed surface. The reference temperature can be measured by means of a contact device for temperature measurement or by applying a special coating with the known emissivity to the examined surface within the field view of the IR camera. The emissivity is determined by adjusting the value from
0 to 1 until the temperature on the IR camera and the reference temperature are equal. ${ }^{11}$

For the purpose of this paper a heat-treat furnace was used for heating the workpieces. For achieving a uniform temperature distribution on the target area of the sample, every workpiece was placed upright in the center of the furnace and tested separately. The radiation emitted from the heat furnace can affect the thermography test to a large extent, especially for alloy Al 6082 due to its high reflectance. Thus, prior to the measurement, a $2-\mathrm{mm}$ black tin box was placed into the furnace in order to eliminate the effect of the furnace walls on the measurement results. The infrared camera used for thermal imaging was camera IR ThermoPro TP8S with a spectral range of $8-14 \mu \mathrm{m}$ and temperature accuracy of $\pm 1{ }^{\circ} \mathrm{C}$. The reference temperature was measured using type-K thermocouples. Two thermocouples were placed on the back surface of the workpiece, whereas the third thermocouple was attached to the front surface of the workpiece using black rubber. The experimental set-up is presented in Figure 1. After installing the thermocouples and setting the IR camera, a workpiece was heated up to $200{ }^{\circ} \mathrm{C}$. Having reached this temperature, the workpiece was being cooled down to the ambient temperature of $25^{\circ} \mathrm{C}$. At the same time, the camera took an IR image of the workpiece at every drop of $10{ }^{\circ} \mathrm{C}$. The described procedure was repeated for every workpiece.

The obtained IR images were processed using the Guide Ir Analyser program where the average emissivity of a workpiece was adjusted to a value from 0 to 1 until the temperature became equal to the reference temperature. During the IR-image processing, the temperature used as the reference temperature was the average of the temperature values obtained with the thermocouples. The described method was used for determining the emissivity of all four workpieces at temperatures from $50{ }^{\circ} \mathrm{C}$ to $200{ }^{\circ} \mathrm{C}$.

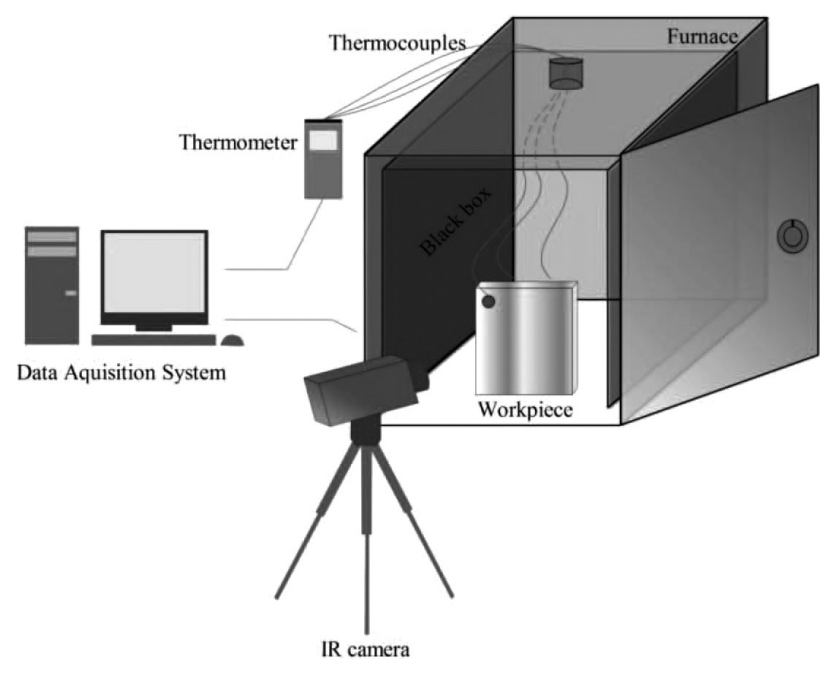

Figure 1: Experimental set-up 


\section{RESULTS AND DISCUSSION}

The experimental data show that the average emissivity of aluminium alloy $\mathrm{Al} 6082$ in the spectral range of $8-14 \mu \mathrm{m}$ decreases during the cooling and mainly increases with an increase in the surface roughness (Figure 2). The emissivity ranges from 0.09 to 0.24 . At temperatures from $50{ }^{\circ} \mathrm{C}$ to $80^{\circ} \mathrm{C}$, the emissivity values of the workpieces are constant, and their mutual differences are only the results of the surface roughness. At temperatures higher than $80{ }^{\circ} \mathrm{C}$, the emissivities rise, first with the $\mathrm{A}_{3}$ workpiece and last with the $\mathrm{A}_{4}$ workpiece. The emissivity of the ground workpiece $A_{1}$ is the lowest and not prone to drastic changes as in the case of the other workpieces, which were milled.

\subsection{Three-dimensional infrared images}

A more through investigation into the effects of the temperature and surface roughness on the emissivity was conducted using 3D IR images. 3D IR images are a three-dimensional representation of the surface of a workpiece with more strictly defined boundaries between the areas with small temperature differences that are almost invisible in a normal IR image. There are various commercial programs for the construction of 3D IR images, but in this paper, a new, original and simple method is presented. The method is based on exporting the temperature values per pixel of an IR image using the Guide Ir Analyser program into a Microsoft Excel table. In the table, the data are grouped in such a way that the $x$ and $y$ coordinates determine the position of a pixel in the IR image, whereas the $\mathrm{z}$ coordinate determines its temperature. With a simple selection of all the data and the construction of a surface-contour diagram in Microsoft Excel, 3D IR images are obtained.

Figure 3 represents $3 \mathrm{D}$ IR images of the ground workpiece $A_{1}$ and the workpiece with the greatest surface roughness, $\mathrm{A}_{4}$, at $200{ }^{\circ} \mathrm{C}$. Their comparison shows that the temperature is more evenly distributed in the $A_{1}$ workpiece due to a more even surface roughness. While

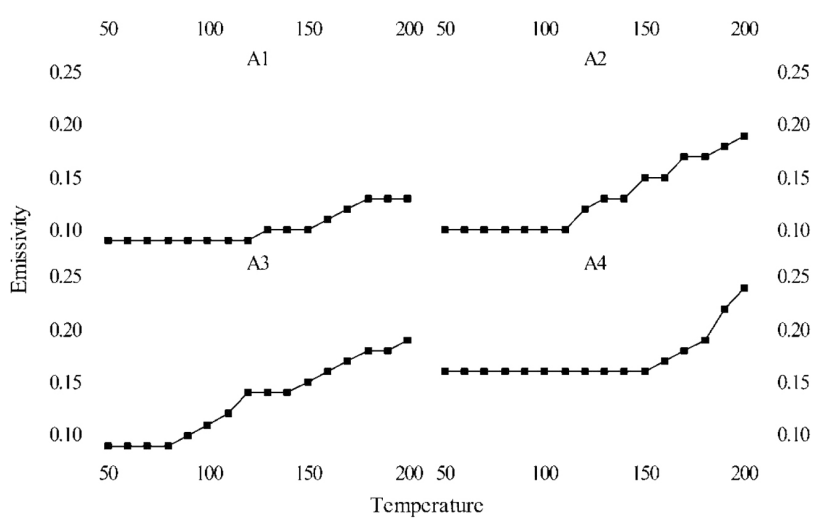

Figure 2: Emissivity of aluminium alloy Al 6082 at low and middle temperatures
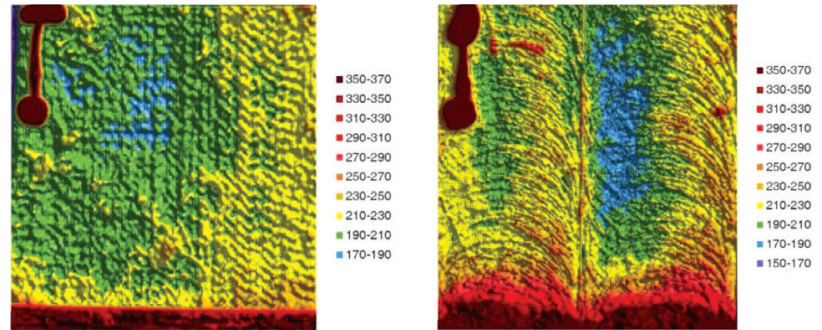

Figure 3: 3D IR images of $\mathrm{A}_{1}$ workpiece at $200{ }^{\circ} \mathrm{C}$ (left) and $\mathrm{A}_{4}$ workpiece at $200{ }^{\circ} \mathrm{C}$ (right)

measuring the arithmetic mean roughness by means of the Mar Surf PS1 device, it was noticed that the left side of the $A_{1}$ workpiece had a greater roughness than the right side, whereas in the $\mathrm{A}_{4}$ workpiece, the opposite was true. These data correspond to the presented 3D IR images of the workpieces. Although the average temperature of both workpieces was $200{ }^{\circ} \mathrm{C}$, in the $\mathrm{A}_{1}$ workpiece, the temperatures from $210{ }^{\circ} \mathrm{C}$ to $230{ }^{\circ} \mathrm{C}$ were more frequent than in the $\mathrm{A}_{4}$ workpiece where the most frequent temperatures ranged from $230{ }^{\circ} \mathrm{C}$ to $250{ }^{\circ} \mathrm{C}$. Plate defects contributed to the higher temperature of the $\mathrm{A}_{4}$ workpiece. The defects are clearly visible in Figure 4 and are represented with red areas, which correspond to the highest temperatures. Apart from this, in the $\mathrm{A}_{4}$ workpiece, an area of low temperatures ranging from $170{ }^{\circ} \mathrm{C}$ to $190{ }^{\circ} \mathrm{C}$ was observed, which is, at the same time, the area with the lowest roughness of the workpiece.

In Figure 3, the temperature of black rubber is above $350{ }^{\circ} \mathrm{C}$ although its real temperature is $200{ }^{\circ} \mathrm{C}$. This error occurred because it is possible to adjust only one value of the emissivity in a $3 \mathrm{D}$ IR image. In this case, the values of the emissivity were adjusted for the $A_{1}$ and $A_{4}$ workpieces, which is why the temperatures of black rubber drastically increased. The effect of reflected radiation on the bottom part of the workpiece is noticeable here as well, leading to the so-called false temperatures. The analysis of the $3 \mathrm{D}$ IR images of the workpieces $\mathrm{A}_{2}$ and $\mathrm{A}_{3}$ showed similarities in the temperature distribution, with clearly visible scratches and the milling direction on the surface, as represented in Figure 4. At higher temperatures, the differences in the surface roughness are more conspicuous than at lower temperatures.

In the 3D IR images of the milled workpieces, the difference in the surface roughness is bigger at the temperature of $200{ }^{\circ} \mathrm{C}$ than at the temperature of $50{ }^{\circ} \mathrm{C}$. At
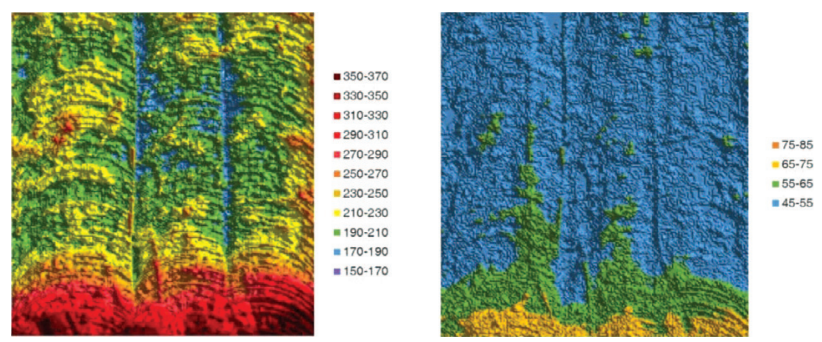

Figure 4: 3D IR images of $\mathrm{A}_{3}$ workpiece at the temperatures of $200{ }^{\circ} \mathrm{C}$ (left) and $50{ }^{\circ} \mathrm{C}$ (right) 
higher temperatures, the milling direction and the boundaries between tool passes are more conspicuous, which can be seen in the 3D IR images of the $\mathrm{A}_{3}$ workpiece whose surface was machined in three tool passes (Figure 4). This leads to a conclusion that the surface roughness causes a greater increase in the emissivity at higher temperatures.

\subsection{Multiple-linear-regression analysis}

A multiple-regression analysis makes it possible to examine the effects of several independent variables on the dependent output variable. The result of this approach is a multiple-regression model that, in the form of a mathematical formula, connects the effects of two independent variables on a dependent variable. ${ }^{12}$ In our case, the dependent variable - the emissivity $(\varepsilon)$ - is related to two independent variables - the temperature $(T)$ and the surface roughness $\left(R_{a}\right)$ using the following model (Equation 1):

$$
\varepsilon=\beta_{0}+\beta_{1} \cdot T+\beta_{2} \cdot R_{a}+r
$$

Where $\beta_{0}, \beta_{1}, \beta_{2}$ represent regression coefficients and $r$ is the component of random error.

For the assessment of the model for $n=64$ observations and the number of independent variables $k=2$, the matrix form of Equation 1 is given by matrix Equation (2):

$$
Y=\left[\begin{array}{c}
e_{1} \\
e_{2} \\
\vdots \\
e_{64}
\end{array}\right] ; X=\left[\begin{array}{ccc}
1 & x_{11} & x_{12} \\
1 & x_{21} & x_{22} \\
\vdots & \vdots & \vdots \\
1 & x_{(64) 1} & x_{(64) 2}
\end{array}\right] ; \beta=\left[\begin{array}{c}
\beta_{0} \\
\beta_{1} \\
\beta_{2}
\end{array}\right] ; \beta=\left[\begin{array}{c}
r_{1} \\
r_{2} \\
\vdots \\
r_{64}
\end{array}\right](2)
$$

Matrix Equation (2) is solved in line with the results from the following multiple-linear-regression model:

$$
\varepsilon=0.000521 \cdot T+0.08635 \cdot R_{a}-0.052
$$

The presented model can be used for the temperature range of $50-200{ }^{\circ} \mathrm{C}$ and surface roughness of 1.07-1.77 $\mu \mathrm{m}$. In this case, the multiple coefficient of determination $R^{2}$ shows that $80.94 \%$ of the variation in the emissivity comes from the variation in the temperature and surface roughness, whereas the remaining $19.06 \%$ is the consequence of the effects of the other parameters such as humidity, permeability of the atmosphere, temperature of the environment, etc. The model can be used for predicting the value of the emissivity at the temperatures and surface-roughness values beyond the mentioned ranges, with a somewhat lower coefficient of determination $R_{\text {pred }}^{2}$ of $78.68 \%$. Multiple regression was used to determine the strength of the dependence between the emissivity and the observed parameters based on the correlation coefficient $r$. The correlation coefficient was 0.9 , pointing to the fact that there is a strong (direct) linear dependence between the temperature and surface roughness and the emissivity.

\section{CONCLUSIONS}

The emissivity of aluminium alloy Al 6082 was experimentally determined in the process of cooling from 200 ${ }^{\circ} \mathrm{C}$ to $50{ }^{\circ} \mathrm{C}$, using the infrared thermography technique. The investigation showed that the emissivity of the chosen alloy ranges from 0.09 to 0.24 , that it decreases with a decrease in the temperature and increases with an increase in the surface roughness. At higher temperatures, the differences between the emissivity values of the workpieces are bigger. The analysis of 3D IR images showed that this phenomenon is a consequence of a more significant effect of the surface roughness on the emissivity at higher temperatures.

Additionally, the paper presents a new method of creating 3D IR images using Microsoft Excel. This method is simple and, unlike commercial programs, it is more affordable. Although the ITT is not recommendable for precise determinations of the emissivity of metals, in the post-processing of the IR images, the authors managed to determine small variations in the emissivity, even when the differences between the IR images were $10{ }^{\circ} \mathrm{C}$. Multiple-regression analysis confirmed a strong correlation between the investigated parameters and the emissivity, and a multiple-regression model was determined.

The presented model can only be applied with low and medium temperatures since at higher temperatures, there is a somewhat greater deviation of the experimental data from the regression line. The reason for this is an uneven distribution of temperature on the surface of a workpiece due to the defects that occurred during the machining.

\section{REFERENCES}

${ }^{1}$ L. Michalski, K. Eckersdorf, J. Kucharski, J. McGhee, Temperature Measurement, Wiley \& Sons, Ltd., Chichester, 2001

${ }^{2}$ B. Kosec, B. Karpe, I. Budak, M. Ličen, M. Đorđević, A. Nagode, G. Kosec, Efficiency and quality of inductive heating and quenching of planetary shafts, Metallurgy, 51 (2012) 1, 71-74

${ }^{3}$ H. Glavaš, L. Jozsa, T. Barić, Infrared thermography in energy audit of electrical installations, Tehn. vjesn., 23 (2016) 5, doi:10.17559/ tv-20150702185559

${ }^{4}$ P. Schreivogel, M. Pfitzner, Optical convective heat transfer measurements using infrared thermography and frequency domain phosphor thermometry, Int. J. Heat Mass Transf., 82 (2015), doi:10.1016/j.ijheatmasstransfer.2014.11.025

${ }^{5}$ M. Švantner, P. Honnerová, Z. Veselý, The influence of furnace wall emissivity on steel charge heating, Infrared Phys. Technol., 74 (2016), 63-71, doi:10.1016/j.infrared.2015.12.001

${ }^{6}$ F. Zhang, K. Yu, K. Zhang, Y. Liu, K. Xu, Y. Liu, An emissivity measurement apparatus for near infrared spectrum, Infrared Phys. Technol., 73 (2015), 275-280, doi:10.1016/j.infrared.2015.10.001

${ }^{7}$ B. Kong, T. Li, Q. Eri, Normal spectral emissivity of GH536 (HastelloyX) in three surface conditions, Appl. Therm. Eng., 113 (2017), doi:10.1016/j.applthermaleng.2016.11.022

${ }^{8}$ C. D. Wen, I. Mudawar, Emissivity characteristics of roughened aluminum alloy surfaces and assessment of multispectral radiation thermometry (MRT) emissivity models, Int. J. Heat Mass Transf., 47 (2004), doi:10.1016/j.ijheatmasstransfer.2004.04.025 
${ }^{9}$ B. Kosec, G. Kosec, Temperature field analysis on active working surface of the die-casting die, Metall., 57 (2003) 3, 134-136

${ }^{10}$ C. D. Wen, I. Mudawar, Modeling the effects of surface roughness on the emissivity of aluminum alloys, Int. J. Heat Mass Transf., 49 (2006), doi:10.1016/j.ijheatmasstransfer.2006.04.037

${ }^{11}$ M. Švantner, P. Vacíková, M. Honner, Non-contact charge temperature measurement on industrial continuous furnaces and steel charge emissivity analysis, Infrared Phys. Technol., 61 (2013), doi:10.1016/ j.infrared.2013.07.005

${ }^{12}$ A. R. Motorcu, Y. Isik, A. Kus, M. C. Cakir, Analysis of the cutting temperature and surface roughness during the orthogonal machining of AISI 4140 alloy steel via the Taguchi method, Mater. Tehnol., 50 (2016) 3, doi:10.17222/mit.2015.021 